\section{B A Institute of \\ YK Business Administration \\ 六下 \\ Karachi \\ Leadership and Ideas for Tomorrow}

Business Review

Volume 8 Issue 1 January-June 2013

$1-1-2013$

\title{
Interdependence of South Asian \& developed stock markets and their impact on KSE (Pakistan)
}

Safdar Hussain Tahir

Government College University, Faisalabad, Pakistan

Hazoor Muhammad Sabir

Government College University, Faisalabad, Pakistan

Follow this and additional works at: https://ir.iba.edu.pk/businessreview

Part of the Business Commons

\section{(c) (1)}

This work is licensed under a Creative Commons Attribution 4.0 International License.

\section{Recommended Citation}

Tahir, S. H., \& Sabir, H. M. (2013). Interdependence of South Asian \& developed stock markets and their impact on KSE (Pakistan). Business Review, 8(1), 85-93. Retrieved from https://doi.org/10.54784/ 1990-6587.1218 


\title{
ARTICLE
}

\section{Interdependence of South Asian \& Developed Stock Markets and their impact on KSE (Pakistan)}

\author{
Safdar Hussain Tahir \\ Government College University, Faisalabad Pakistan \\ Hazoor Muhammad Sabir \\ Government College University, Faisalabad Pakistan
}

\begin{abstract}
The objective of this study was to investigate the interdependence among the South Asian and developed markets and their impact on Karachi Stock Exchange. The data was collected from eight worldly stock exchanges, four from each South Asia and developed countries for the period starting from July 1999 to June 2011. For analytical purposes, techniques like Correlation Matrix, Unit root, Co integration test and Granger Causality were applied. The correlation results indicated that there was no significant relationship between the South Asian and developed equity markets. However the equity market of US and India found to be correlated. A bidirectional casual relationship was found between CSE and KSE through Granger Casual test. The Equity Markets of South Asia and Developed countries are not co integrated with each other. The international portfolio managers are advised to include Karachi Stock Markets in the developed market portfolios, because the Karachi Stock Market is not linked with the Developed world.
\end{abstract}

Keywords: Stock Exchange, South Asian, Developed markets, Interdependence.

\section{Introduction}

The stock market is a place where the stocks of listed companies are traded. It is also called equity market. The listed companies are those companies whose shares are available on a stock exchange for public trading. It is an important source for companies to raise money. The stock exchanges operate as clearing house, similar to financial institutions that reduce the risk of default on the transaction. The stock market is one of the important sources that perform important role in nation economy.

According to the theory the world markets are integrated with each other. The information flowing from one market may affect the other markets because of integration. Stock Markets are said to be integrated if they move together in same direction. There are many factors that are contributing in financial markets integration. These include the following:

(1) Free flow of capital

(2) Increase in flow of information 
(3) Reduction in transaction cost.

Topic has gained great importance since after the stock market crash of October 1987 the integration of global equity markets has been studied by different researchers. Mostly the studies are related to the developed countries. The international fund managers invest in those markets which are not independent.

Globalization also plays a vital role in equity markets. Globalization depicts a process through which the national economies have become integrated. After globalization, financial markets have started changing. Globalization is the main factor behind the diversification of stock markets. It means reducing the risk by investing in multiple of assets.

According to the Markowitz (1952, 1959), the investor should hold a well-diversified portfolio of several securities which should be negatively correlated with one another. Moreover, the negatively correlated securities, assume the benefit of diversification. These benefits achieved by investing in international markets. There are two types of diversification (Random and Non Random). Markowitz prefers Non-random diversification. The theory states that, the investors should invest on the basis of variance, covariance and correlation, rather than blindly investing in an asset.

Kedarnath Mukherjee and R. K. Mishra, Suchismita Bose found the stock market interlink ages in Indian markets. Recently Arshad et al (2008) examined the long run relationship between an Emerging Equity Market and Equity Markets of the Developed World.

Some studies state that the some Asian markets are co integrated with markets of developed world but some suggest otherwise. In this study we re-examine this issue. The South Asian countries experienced political and economic circumstances in past years i.e. Asian Financial crises and the terrorist attack in September 2001.

\section{Overview of South Asian Stock Markets}

South Asia consists of eight countries like Bangladesh, Bhutan, India, Maldives, Nepal, Pakistan, Sri Lanka and Afghanistan. These countries have many regional stock exchanges. Pakistan has three stock exchanges; the Islamabad Stock Exchange (ISE), Lahore Stock Exchange (LSE) and Karachi Stock Exchange (KSE). Among these the KSE coves the biggest share of Pakistan. The Karachi Stock Exchange was established in 1948. It is the largest and oldest exchange. Second to the Karachi Stock exchange is the Lahore Stock Exchange which was launched in 1970. The LSE has 519 listed companies. The third important national exchange is the Islamabad Stock Exchange was established in 1989. It started trading in July 1992.

India is among the top emerging markets in South Asia with almost more than 20 regional stock exchanges. The Bombay Stock Exchange and the National Stock Exchange of India Ltd. are the two primary exchanges in India. The BSE and NSE are two leading exchanges and account for about 80 per cent of the equity volume traded in India. Mumbai Stock Exchange (BSE), Delhi Stock Exchange and Calcutta Stock Exchanges account for more than fifty percent of listed companies in India. 
There are 34 developed countries in the World. The Australian Securities Exchange (ASX) is the main stock in Australia. The ASX was established in 1861.The major market index is the S\&P / ASX 200. The Tokyo Stock Exchange was established in 1878, The Tokyo Stock Exchange (TSE) is the second largest stock exchange in the world by aggregate market capitalization of its listed companies. The Tokyo Stock Exchange has 2,412 listed companies in 2010. The main indices tracking the TSE are the TOPIX and Nikkei 225.

\section{Problem statement}

Investors always try to lessen their risks in investment by diversifying their portfolios. In order to identify the different portfolios where they could invest, no visible signs exist which may direct them for investment. This is a problem of prime importance to be identified. In the existing scenarios of national economy, no empirical work has been done yet which may lead the national investors. Therefore, the current study is endeavoring to quantify and identify the impact of various Worldly Stock markets upon one another. The mutual interdependence of these markets will also be detected. It will work like a guiding star for the investors to diversify their national and international portfolios for investment.

\section{Research objective}

Following are the perceived objectives of this research

To find out whether the stock markets in South Asia (Pakistan, India, Sri Lanka and Bangladesh) are interlinked.

To explore the long run and short run relationship among South Asian and developed countries.

To assess the Interdependence of worldly Stock Markets and their impact on Karachi Stock Exchange.

To examine the linkages among the South Asian and developed equity markets and to see the scope of portfolio diversification within the region.

\section{Literature Review}

Owen Bleeders (2002) explained the interdependence between South Africa and both the UK and US. He used the variable approach. According to the results, little interdependence was found before 1995 when dual exchange rates existed. The interdependence between South Asia and US increased after the unification and removal of exchange rates. And also increased after March 1995 when the US purchases increased.

Paresh Narayn et al. (2003) examined the linkages among four South Asian Stock Markets Pakistan, India, Bangladesh and Sri Lanka using temporal granger causality approach. And found the relationship among the stock price indices within a multivariate co integration framework. He also proved the impulse response functions. Results showed unidirectional granger causality from stock prices in Pakistan to Stock Prices in India, Daily Stock Prices indices were used in this study over the period 1995 to 2001. Bangladesh was found most exogenous among these four due to small size and market capitalization. 
Lambda (2005) analyzed the short and long run relationship between South Asian equity markets and developed equity markets during July 1997 to December 2003. He used the multivariate co integration framework. According to his results, the Indian market is influenced by the equity market of developed countries (US, UK and Japan).The Pakistani and Sri Lankan markets are independent and having no co integration with the developed equity markets.

Abbas Valadkhani (2007) investigated the co integration and causality between the stock market price indices of Thailand and international stock markets (Australia, Hong Kong, Indonesia, Japan, Korea, Malaysia, the Philippines, Singapore, Taiwan, the UK and the USA), using monthly data from December 1987 to December 2005. According to Granger causality test, the stock returns of Thailand and three of its neighboring countries (Malaysia, Singapore and Taiwan) are unified.

Arshad et al (2008) examined the long term relationship between Karachi stock exchange and equity markets of developed world for the period of 2000 to 2006 using multivariate co integration analysis. According to their findings pair wise Co integration analysis showed that Karachi stock market was not co integrated with equity market of developed world, but Karachi stock exchange was found to be integrated with France and Japan. Co integration analysis indicates that markets are integrated and there exists a long term relationship between these markets.

B.J.Queensly Jeyanthi (2009) investigated the one word ages and volatility spillovers under market reforms, and examined to what extend Indian stock markets are integrated with stock markets of the US, UK and Japan and also found the relationship between the stock prices of India. According to findings, long run relationships were found between the stock prices of India and its major trading partners before and after the structural changes. In short run, Granger causality exists between the stock returns of India and US, UK and Japan after the structural changes but unidirectional relationship exists between India and the UK before the structural changes. According to our view, these differences are due to structural change. Causality model states that volatility spill-over from Japan and UK did not exist before the structural changes. UK and Japan were not well-defined before the structural changes and U.S and Japan were welldefined after the structural changes. So, the US and Japan markets are generating the spillover in New York Stock Exchange (NYSE).

\section{Methodology}

\section{Population}

The stock markets in South Asia and other developed countries of the world constitute the population for this study. South Asia consists of eight countries, Bangladesh, Bhutan, India, Maldives, Nepal, Pakistan, Sri Lanka and Afghanistan while according to IMF there are 34 developed countries. These countries have many regional stock exchanges. 


\section{Sample}

A sample of eight equity markets was taken which included four South Asian and four Developed Stock markets. It was both a convenient and purposive sample. The research to be conducted was a quantitative research. Secondary data was used. The data was collected from secondary sources like internet and other bulletins etc. Supportive data was collected from previous research papers related to this topic. The data employed in this study included monthly closing stock market indices. The stock markets include the KSE-100 index (Pakistan), BSE (India), CSE All shares (Sri Lanka), General index (Dhaka), Standard \&Poor 500 index (US), FTSE 100(UK), AORD Index (Australia), Nikkei 225(Japan). The data collection period extended over a twelve years period from Jul 30, 1999 - Jun 30, 2011.

\section{Hypothesis}

The purpose of this research was to investigate the interdependence among the South Asian and Developed world stock markets and their impact on KSE. The hypothesis in this regards were; $\mathrm{Ho}_{1}$ : No causal relationship exists among the South Asian and developed stock markets.

$\mathrm{Ho}_{2}$ : There is no association among the south Asian stock markets and KSE.

$\mathrm{Ho}_{3}$ : The developed stock markets have no impact on KSE.

\section{Theoretical Model of Research}

\section{Model-1}

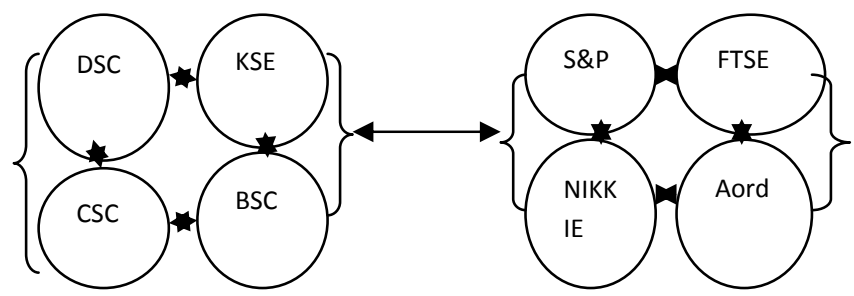

Model-2

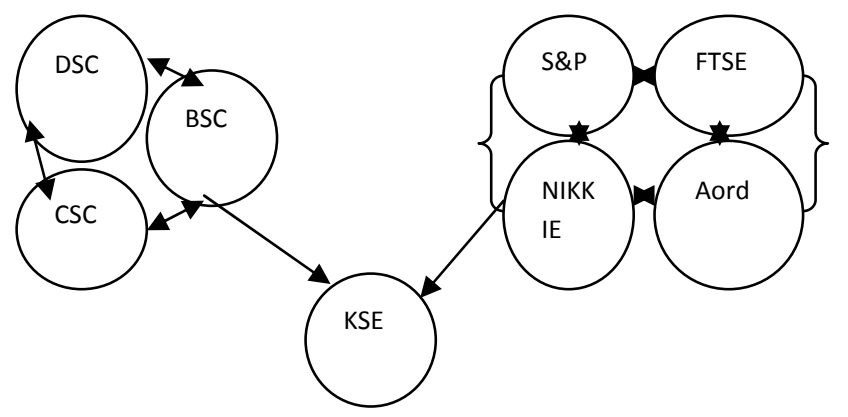




\section{Major Variable of Study:}

The major variable of interest was the rate of return in different stock markets of the world.. The continuous compounded rate of return was calculated by using the following formula:

Rat $=\operatorname{Ln}(\mathrm{Pt} / \mathrm{Pt}-1)$

Where:

Rat = Return on day's';

$\mathrm{P} \mathrm{t}=$ Index closing value on week's'

Pt-1=Index closing value on week't-1'

$\mathrm{Ln}=$ Natural Log

In this study the basic purpose was to analyze the interdependence among the equity markets of south Asia and developed world and their impact on Karachi stock exchange, so the different techniques applied are (i) Correlation Analysis (ii) Unit Root Test (iii) Co integration tests (vi) Granger causality test.

\section{Correlation Statistics}

It is an econometric technique which is used to describe the degree of relationship between the two variables. In this study the relationship between rate of return of south Asian and developed stock markets were estimated by using the following formula:

$$
r=\frac{\operatorname{SS}(x y)}{\sqrt{\operatorname{SS}(x) \operatorname{SS}(y)}}
$$

There are three types of relationships. Such as

(i) $\quad+1$ perfect positive relationship

(ii) -1 perfect negative

(iii) 0 no correlation

\section{Unit Root Test}

As the data evolved were of time series in nature. It is necessary to check its stationarity before the application of any economic technique. For this purpose the most frequently used ADF test was applied. For unit root analysis, the model applied was

$$
\Delta Y_{t}=(\rho-1) Y t-1+U_{t}=\delta Y_{t}-1+U_{t}
$$

Where

$\mathbf{Y}_{\mathbf{t}}$ is the variable of interest,

$\mathbf{t}$ is the time index,

$\boldsymbol{\rho}$ is a coefficient,

$\mathbf{U}_{\mathbf{t}}$ is the disturbance term.

Where $\Delta$ is the first difference operator 
$\boldsymbol{\delta}<0$ then it indicates that data series stationary and vice versa

\section{Co integration test}

Co integration analysis was, firstly used by Johansen \& Josuilius. It can be applied to test the existence of $r$ co integrating vectors. (1) Maximal Eigen value, the maximal Eigen value test the null hypothesis that the no of Co-integrating relationships was less than or equal to or against the alternative $\mathrm{r}+1$. (2) The Trace statistics. The trace statistic is the null hypothesis of $\mathrm{r}$ Cointegrating against the alternative of $\mathrm{r}$ or more Co-integrating vectors.

\section{Granger causality test}

In next step Granger Causality test was applied. It is the test which helps researchers to determine the direction of cause i.e. whether

$\mathrm{Y} \leftrightarrow \mathrm{X}$

In order to test this hypothesis the $\mathrm{F}$ test in the form given below was applied

$\mathbf{F}=\left\{\left(\mathbf{R S S}_{\mathbf{r}}-\mathbf{R S S}_{\mathrm{ur}}\right) / \mathrm{M}\right\} \div\left(\mathrm{RSS}_{\mathrm{ur}} / \mathbf{n}-\mathbf{k}\right)$

Where

RSSr is the restricted residual sum of squares

RSSur is the unrestricted residual sum of squares

$\mathrm{M}$ is the lag term and $\mathrm{n}-\mathrm{k}$ is the degree of freedom.

If the computed value exceeds critical value of $\mathrm{F}$ at some chosen level of significance, then null hypothesis rejected and it is concluded that $\mathrm{Y}$ is the cause of $\mathrm{X}$. Such test could be repeated for identification of cause for other variables as well.

\section{Results}

The data given table-1 indicated that there was no significant relationship between the South Asian equity markets. On the other side strong evidences of correlation were found among the developed equity market. The South Asian countries had minimum correlation coefficients with Karachi stock exchange indicating that there was no strong influence on it except CSE. On the other hand the impact of developed countries stock markets on Karachi stock exchange was greater than South Asian. The major influence on KSE was from AORD (Australia).

\section{Correlation Matrix}

\section{Table-1}

\begin{tabular}{|l|l|l|l|l|l|l|l|l|}
\hline & KSE & DSE & BSE & CSE & FTS E & AORD & S\&P & $\begin{array}{c}\text { Nikkei- } \\
\text { Rtn }\end{array}$ \\
\hline KSE & 1 & & & & & & & \\
\hline DSE & $\mathbf{0 . 0 6}$ & 1 & & & & & & \\
\hline
\end{tabular}


Business Review - Volume 8 Number 1

\begin{tabular}{|l|l|l|l|l|l|l|l|l|}
\hline CSE & 0.67 & 0.02 & 1 & & & & & \\
\hline BSE & $\mathbf{- 0 . 0 5}$ & 0.08 & 0.04 & 1 & & & & \\
\hline FTSE & 0.12 & 0.07 & 0.10 & 0.01 & 1 & & & \\
\hline AORD & 0.23 & 0.06 & 0.29 & 0.04 & 0.73 & 1 & & \\
\hline S\&P & 0.15 & 0.11 & 0.14 & 0.06 & 0.83 & 0.71 & & \\
\hline $\begin{array}{l}\text { Nikkei- } \\
\text { Rtn }\end{array}$ & 0.17 & 0.04 & 0.24 & 0.01 & 0.59 & 0.70 & 0.59 & 1 \\
\hline
\end{tabular}

\section{Unit root test}

Table-2

\begin{tabular}{|c|c|c|c|c|}
\hline & ADF -Level & ADF-Ist diff & PP-Level & $\begin{array}{l}\text { PP-Ist } \\
\text { diff }\end{array}$ \\
\hline KSE & -1.176 & -9.47 & -1.21 & -9.46 \\
\hline DSE & -0.387 & -10.79 & -0.55 & -10.92 \\
\hline CSE & -0.89 & -8.98 & -0.94 & -9.00 \\
\hline BSE & -0.53 & -8.56 & -0.79 & -8.66 \\
\hline FTSE & -1.38 & -10.6 & -1.46 & -10.60 \\
\hline AORD & -1.26 & -8.22 & -1.33 & -8.37 \\
\hline S\&P & -1.24 & -10.16 & -1.36 & -10.15 \\
\hline Nikkei & -1.48 & -9.255 & -1.700 & -9.33 \\
\hline
\end{tabular}

The Table-2 presents the results of the unit root test for the South Asian markets. According to the test description if the value of $\operatorname{ADF}(\delta)$ is below zero, then it is concluded that data series are stationary. The data given in the table 4.2 depict that the ADF test value at level as well as at first difference was less than zero for both South Asian and developed equity markets. Thus, it was concluded that the data series were stationary.

\section{Co Integration Analysis}

Table-3

\begin{tabular}{|l|r|r|r|r|}
\hline Hypothesized & \multicolumn{1}{|l|}{ Eigen value } & \multicolumn{1}{l|}{ Trace Statistic } & C Value at 0.05 & Prob. \\
\hline KSE $*$ & 0.369 & 212.414 & 159.529 & 0 \\
\hline DSE $*$ & 0.344 & 159.433 & 125.615 & 0.0001 \\
\hline CSE $^{*}$ & 0.266 & 110.813 & 95.753 & 0.0031 \\
\hline BSE $*$ & 0.242 & 75.1855 & 69.818 & 0.0175 \\
\hline FTSE & 0.137 & 43.279 & 47.856 & 0.1259 \\
\hline AORD & 0.114 & 26.253 & 29.797 & 0.1213 \\
\hline S\&P & 0.076 & 12.299 & 15.494 & 0.1431 \\
\hline Nikkei & 0.027 & 3.169 & 3.841 & 0.075 \\
\hline
\end{tabular}


The data given in table Table-3 demonstrate the co integration results. It includes the Trace Statistics and Eigen value. Trace statistics confirmed the long run co integration among Equity markets of South Asian. Max Eigen value indicates also verified the long run Co-integration existed among KSE and DSE.

\section{Granger causality test}

Granger Causality test was used to determine the co integration among the variables. It showed the causality among the variables. In table-4 the results indicated that CSE (Colombo Stock Exchange) influence KSE and KSE also influenced CSE, their values were .03 and .02 respectively. BSE (Bangladesh Stock Exchange) also Granger cause the KSE, and KSE also Granger cause BSE, their values were .01 and .03 respectively. This showed there existed bidirectional granger causality between some south Asian markets and Karachi equity market.

\section{Table-4}

\begin{tabular}{|l|r|r|}
\hline Null Hypothesis: & F-Statistic & Prob. \\
\hline CSE does not influence KSE & 3.06368 & 0.0311 \\
\hline KSE does not influence CSE & 3.14056 & 0.0282 \\
\hline BSE does not influence KSE & 3.87242 & 0.0112 \\
\hline KSE does not influence BSE & 3.05541 & 0.0314 \\
\hline KSE does not influence FTSE & 3.04977 & 0.0317 \\
\hline AORD does not influence KSE & 3.40456 & 0.0202 \\
\hline KSE does not influence S\&P & 3.28813 & 0.0234 \\
\hline KSE does not influence NIKKIE & 4.52498 & 0.005 \\
\hline CSE does not influence BSE & 3.53129 & 0.0173 \\
\hline FTSE does not influence CSE & 3.37204 & 0.0211 \\
\hline AORD does not influence CSE & 3.25798 & 0.0244 \\
\hline S\&p does not influence CSE & 2.52083 & 0.0616 \\
\hline NIKKIE does not influence CSE & 5.23868 & 0.002 \\
\hline FTSE does not influence Granger Cause BSE & 19.3985 & $4.00 \mathrm{E}-10$ \\
\hline AORDdoes not influence Granger Cause BSE & 28.4276 & $1.00 \mathrm{E}-13$ \\
\hline S\&P does not influence Granger Cause BSE & 18.7466 & $7.00 \mathrm{E}-10$ \\
\hline S\&P does not influence Granger Cause BSE & 28.8121 & $8.00 \mathrm{E}-14$ \\
\hline FTSE does not influence Granger Cause & 3.46795 & 0.0187 \\
\hline NIKKIE & & \\
\hline
\end{tabular}


The results indicated that the developed equity markets were also Granger Cause equity markets of south Asia. In developed countries KSE Granger cause the FTSE but FTSE did not Granger cause the KSE, their values were .03 and .166 respectively. It was unidirectional phenomenon. AORD Granger causes the KSE and P-values were .020. KSE also Granger causes the Nikkei at .005. FTSE\& Nikkei Granger caused on CSE respectively at .002 and 4.00e-10. AORD Granger causes the BSE because the P-values are 1.00e-13. This is less than 0.05. S\&P Granger causes the BSE and P-values are 8.00e-14. There no Granger Causality Existed between Developed countries except FTSE. FTSE Granger caused Nikkei respectively at 0.018 .

\section{Conclusions}

The main purpose of this study was to investigate the interdependence of South Asian and Developed stock markets and their impact on Karachi stock exchange. The different techniques were applied to test the interdependence.

1. There was lack of intra relationship among South Asian stock markets.

2. Weak correlation among developed stock markets was observed.

3. No significant impact of both Asian and developed market was found on KSE.

4. On the other side European, Australian, American \& Japanese equity markets are strongly co related with each other, which may be due to the financial integration of markets and also the free flow of funds among the countries. So, there is an opportunity for international fund managers to invest in South Asian countries.

5. According to Granger Causality test the Karachi Stock Market is integrated with the BSE \& CSE. investors of these two countries cannot get benefit by investing in KSE. The other South Asian markets not granger cause each other. However unidirectional causality exists among AORD \& KSE and among KSE and S\&P. Pair wise Granger Causality test also indicates that the Karachi Stock Market is not integrated with the Developed Equity Markets.

\section{Recommendations}

According to the results of this study, we are able to give the following recommendations.

1. The international portfolio managers are advised to include Karachi Stock Markets in the developed market portfolios, because the Karachi Stock Market is not linked with the Developed world.

2. The international investors should not invest in US and India at same time. Because equity markets of US and India are positively correlated with each other. They should choose one of them for investment.

3. The Karachi Stock Market is integrated with Bombay and Colombo Stock Market. So the investors of these two countries cannot acquire benefit by investing in KSE.

4. European, American, Australian, \&Japan equity markets are strongly co related with each other so investing in these countries are not beneficial for investors.

5. The Equity Markets of South Asia and Developed countries are not co integrated with each other. The international fund managers should take the benefits of diversification by investing in these stock exchanges. 柴 


\section{References}

Abbas Valadkhani, may 2007, "Dynamic linkages between Thai and international stock markets",

Arshad et all (2008), "Long-Run Relationships between an Emerging Equity Markets and Equity Markets of the Developed World an Empirical Analysis of Karachi Stock Exchange". International Research Journal of Finance and Economics, 1450-2887

B.J.Queensly Jeyanthi,2009, “'Interdependence and Volatility Spillovers under Market Reforms:

Glezakos M., Merika A., Kaligosfiris. H (2007)," Interdependence of Major World Stock Exchanges: How is the Athens Stock Exchange Affected?" International Research Journal of Finance and Economics" Issue 7 (2007)

Oxford Bulletin of Economics and Statistics, 54 (3):383-397.

Lamba (2005), "Analysis of the Short- and Long-Run Relationships between South Asian and Developed Equity Markets”, International Journal of Business, 10(4), 2005 ISSN: 1083-4346

Markowitz, H. Portfolio Selection, Journal of Finance 7 (1952).

Markowitz, H. Portfolio Selection. (Cambridge, MA: Basil Blackwell, 1959)

Mukherjee Kedarnath and Mishra, R.K., "Information Role of Non-Price Variables: An Empirical Study of Indian Options Market”, The ICFAI Journal of Applied Finance, 13 (2), 2007, pp. 32-45.

Paresh Narayan, Rusell Smyth and Mohan Nandha (2003), "Interdependence and dynamic linkages between the emerging stock markets of South Asia" 